\title{
EVALUATION OF PLATELET NUMBER AND FUNCTION AND FIBRINOGEN LEVEL IN PATIENTS BITTEN BY SNAKES OF THE BOTHROPS GENUS
}

\author{
Fábio Cardoso Iuan, Izolete Aparecida Thomazini, Iracema Carvalho, Delane \\ Mercedes Gonçalves Carreira, Valter José Cassinelli, Paulo Câmara Marques \\ Pereira and Benedito Barraviera
}

\begin{abstract}
Platelet function and plasma fibrinogen levels were evaluated in 14 patients, 10 males and 4 females, aged 13-59 years bitten by Bothrops genus snakes. There was a statistical difference $(p<0.05)$ among plasma fibrinogen levels evaluated 24 and 48 hours after envenomation. There was a tendency towards normalization after 48 hours of treatment. The low platelet number was clear in 24-48 hour evaluations with a tendency towards normalization after 48 hours of treatment $(p<0.05)$. When platelet function was stimulated by collagen and epinephrine, it appeared to be within normal values. On the other hand, when it was stimulated by adenosine diphosphate $(A D P)$, platelet function was hypoaggregated by a single micromol concentration until 48 hours after treatment. At a 3 micromol concentration, there were alterations only before specific treatment $(p<0.05)$. Fibrinogen levels and fibrin degradation product (FDP) levels appeared to be altered in $83.33 \%$ of patients evaluated. The authors suggest that platelet hypoaggregation is related to decreased fibrinogen and increased FDP levels.
\end{abstract}

Key-words: Platelet function. Fibrinogen. FDP. Bothrops.

Envenomations are a serious health problem in tropical countries ${ }^{125}$. In Brazil around 20,000 envenomation cases occur every year, 2,000 of them only in the State of São Paulo ${ }^{1}$. About $80 \%$ of the cases occurring in Botucatu area are caused by three species of Bothrops (B. jararaca, B. alternatus and $B$. neuwiedi) $)^{2}$.

Local and systemic alterations are occasioned by Bothrops venom when inoculated in humans ${ }^{19}$ 20. Proteolytic venom fractions ${ }^{1}$ result in tissue necroses. Hemorrhagic and coagulant fractions act on the systemic level leading to vessel and blood changes $^{79}$. Blood white cells, platelets and coagulant factor alterations are observed ${ }^{7}$. Coagulant factor changes have been demonstrated in vitro and ex vivo experiments ${ }^{7} 1416$. Factors II and X are activated with consequent fibrinogen consumption ${ }^{7} 1416$. Platelet changes have been observed in accidents

\footnotetext{
Faculdade de Medicina de Botucatu e Centro de Estudos de Venenos e Animais Peçonhentos da Universidade Estadual Paulista, Botucatu, SP.

Address to: Dr. Benedito Barraviera. CEVAP/FM/UNESP. Caixa Postal 576, 18618-000 Botucatu, SP, Brasil.

Recebido para publicação em 23/05/94.
}

caused by different snakes ${ }^{7} 1526$. Thomazini et alii $^{23}$ demonstrated a decrease of platelet aggregation activity in patients bitten by Crotalus snakes. On the other hand, Zingali et aliii ${ }^{27}$ showed an increase of platelet aggregation activity in vitro. Based on these data, the aggregant or anti-aggregant effect caused by different snake venoms is controversial ${ }^{23}$ 2627.

The objectives of the present study were to evaluate the number and platelet function, as well as fibrinogen and FDP plasma levels in patients bitten by Bothrops snakes.

\section{MATERIALS AND METHODS}

Fourteen patients, bitten by Bothrops snakes, 10 males and 4 females aged 13-59 years, admitted to the Tropical Diseases Service of the School of Medicine of Botucatu/UNESP were studied. Blood samples were collected immediately after the patients' admission, 24, 48 hours and 8 days after the specific treatment for hemostatic system evaluation. All patients were treated with specific antivenom according to several authors ${ }^{120}$. 
Iuan FC, Thomazini IA, Carvalho I, Carreira DMG, Cassinelli VJ, Pereira PCM, Barraviera B. Evaluation of platelet number and function and fibrinogen level in patients bitten by snakes of the Bothrops genus. Revista da Sociedade Brasileira de Medicina Tropical 28:19-24, jan-mar, 1995.

Fibrinogen plasma levels were measured by Ratnoff and Menzie method ${ }^{18}$. Platelet function was evaluated by stimulating aggregation with 1 micromol $(\mu \mathrm{m})$ and $3 \mu \mathrm{m}$ adenosine diphosphate , collagen and epinephrine from Helena Laboratories ${ }^{5}$ by using a Zenith platelet aggregation for the graphic record. Numerical score of platelets was made utilizing the Newbauer chamber method by phase contrast. Fibrin degradation product (FDP) levels were determined in serum through the latex proof with the American Dade reagents.

Statistical analyses were carried out using the Wilcoxon non-parametric proof or two dependent samples ${ }^{4}$.

\section{RESULTS}

Table 1 shows fibrinogen plasma levels decreased before and after 24 hours after the specific treatment $(p<0.05)$. Forty-eight hours later the level augmented and remained stable until 8 days. The number of platelets was low before, 24 and 48 hours after specific treatment returning to the normal on the $8^{\text {th }}$ day $(\mathrm{p}<0.05)$.

Table 2 shows platelet stimulation with $1 \mu \mathrm{m}$ and $3 \mu \mathrm{m}$ ADP. When stimulated by $1 \mu \mathrm{m}$ ADP, platelets were hypoaggregant until 48 hours after treatment with a tendency to normalization on the $8^{\text {th }}$ day $(p<0.05)$. When ADP concentration was increased to $3 \mu \mathrm{m}$, the platelets were hypoaggregant in the 24-hour evaluation tending to normalization after 48 hours $(p<0.05)$.

Table 1 - Fibrinogen plasmatic levels and platelet count of patients sudied. Results are reported as means $\pm S D$.

\begin{tabular}{|c|c|c|c|c|}
\hline & $\begin{array}{c}\text { A } \\
\text { Before }(n=14)\end{array}$ & $\begin{array}{c}\text { B } \\
24 h r(n=12)\end{array}$ & $\begin{array}{c}C \\
48 h r(n=12)\end{array}$ & $\begin{array}{c}\text { D } \\
8^{\text {th }} \text { day }(n=8)\end{array}$ \\
\hline \multicolumn{5}{|l|}{ Fibronogen (1) } \\
\hline $\begin{array}{l}\text { Normal: } \\
200 \text { a } 400 \mathrm{mg} \%\end{array}$ & $211.5 \pm 70.19$ & $223.83 \pm 36.13$ & $261.73 \pm 72.79$ & $289 \pm 47.02$ \\
\hline \multicolumn{5}{|l|}{ Platelets (2) } \\
\hline $\begin{array}{l}\text { Normal: } \\
200 \text { a } 400 \times 10^{8}\end{array}$ & $158.14 \pm 110.35$ & $182.55 \pm 71.64$ & $158.25 \pm 55.89$ & $194.13 \pm 46.71$ \\
\hline
\end{tabular}

Table 2 - Platelet aggregation activity with $1 \mu m$ and $3 \mu m$ ADP of patients studied. Results are reported as means $\pm S D$.

\begin{tabular}{lcccc}
\hline & A & B & C & D \\
& Before $(\mathrm{n}=14)$ & $24 \mathrm{hr}(\mathrm{n}=12)$ & $48 \mathrm{hr}(\mathrm{n}=9)$ & $8^{\text {th }}$ day $(\mathrm{n}=7)$ \\
\hline $\begin{array}{l}\text { Stimulated with } \\
\text { ADP } 1 \mu \mathrm{m}(1) \\
\text { (normal }>60 \%)\end{array}$ & $17.84 \pm 28.69$ & $23.17 \pm 28.73$ & $18.90 \pm 21.84$ & $37.57 \pm 29.09$ \\
$\begin{array}{l}\text { Stimulated with } \\
\begin{array}{l}\text { ADP } 3 \mu \mathrm{m}(2) \\
\text { (normal }>60 \%)\end{array}\end{array}$ & $35.76 \pm 32.98$ & $58.41 \pm 23.71$ & $62.66 \pm 15.44$ & $66.57 \pm 25.04$ \\
\hline
\end{tabular}

Statistical analysis:

$A_{1} \times B_{1} \times C_{1} \times D_{1} ; A_{1}=B_{1}=C_{1}<D_{1} ;(p<0,05)$

$A_{2} \times B_{2} \times C_{2} \times D_{2} ; A_{2}<B_{2}=C_{2}=D_{2} ;(p<0,05)$ 
Iuan FC, Thomazini IA, Carvalho I, Carreira DMG, Cassinelli VJ, Pereira PCM, Barraviera B. Evaluation of platelet number and function and fibrinogen level in patients bitten by snakes of the Bothrops genus. Revista da Sociedade Brasileira de Medicina Tropical 28:19-24, jan-mar, 1995.

Table 3 shows no alteration when platelets were stimulated by collagen and epinephrine.

Table 4 shows fibrinogen plasma levels and fibrin degradation products (FDP) increased in 5 out of 6 patients studied. Three patients presented values up to $40 \mathrm{micrograms} / \mathrm{ml}$, while the other two presented levels of $10-40 \mu \mathrm{g} / \mathrm{ml}$. The only patient with normal FDP $(<10 \mu \mathrm{g} / \mathrm{ml})$ values showed normal platelet activity and normal fibrinogen values.

\section{DISCUSSION}

Blood coagulation changes both in vitro and $e x$ vivo have been observed in envenomations caused by different venomous snakes ${ }^{6} \quad \begin{array}{llllll}13 & 14 & 20 & 21 & 23 & \end{array}$. Kornalik $^{8}$ working in vitro with snake venoms of Agkistrodon and Vipera genera demonstrated that a fibrinogen bovine solution, when pre-incubated with these venoms, lost its capacity of turning into fibrin. Kamiguti et alii ${ }^{6}$, studying patients bitten by Bothrops jararaca, noticed fibrinogen consumption. Studies carried out by Thomazini et alii ${ }^{23}$ in patients bitten by Crotalus durissus terrificus, agree with the results obtained by Kamiguti et alii ${ }^{6}$. Santoro et alii ${ }^{22}$ inoculating Bothrops jararaca venom in rabbits observed low plasmatic fibrinogen levels and increased levels of fibrin degradation products (FDP). Sano-Martins et aliii ${ }^{21}$ studied patients bitten by Bothrops and found high levels of FDP immediately before antivenom therapy, tending to normalize after a 24-hour treatment.

In this study, immediately and 24 hours after the accident, fibrinogen plasmatic levels showed a decrease, but were still within normal values. These normalized 48 hours after specific treatment. A

Table 3 - Platelet aggregation activity with collagen and epinephrine of patients studied. Results are reported as means $\pm S D$.

\begin{tabular}{|c|c|c|c|c|}
\hline & $\begin{array}{c}\text { A } \\
\text { Before }(n=14)\end{array}$ & $\begin{array}{c}\text { B } \\
24 \mathrm{hr}(\mathrm{n}=12)\end{array}$ & $\begin{array}{c}\mathrm{C} \\
48 \mathrm{hr}(\mathrm{n}=11)\end{array}$ & $\begin{array}{c}D \\
8^{\text {th }} \text { day }(n=7)\end{array}$ \\
\hline $\begin{array}{l}\text { Collagen }(1) \\
(5 \mu \mathrm{g} / \mathrm{ml}) \\
(\text { normal }>60 \%)\end{array}$ & $49.64 \pm 33.13$ & $74.17 \pm 12.92$ & $75.73 \pm 13.42$ & $77.43 \pm 12.33$ \\
\hline $\begin{array}{l}\text { Epinephrine }(2) \\
(30 \mu \mathrm{m}) \\
(\text { normal }>60 \%)\end{array}$ & $45.35 \pm 30.92$ & $76.25 \pm 14.76$ & $67.27 \pm 19.50$ & $72.29 \pm 17.77$ \\
\hline
\end{tabular}

Statistical analysis:

$$
\begin{aligned}
& A_{1} \times B_{1} \times C_{1} \times D_{1} ; A_{1}<B_{1}=C_{1}=D_{1} ;(p<0,10) \\
& A_{2} \times B_{2} \times C_{2} \times D_{2} ; A_{2}<B_{2}=C_{2}=D_{2} ;(p<0,10)
\end{aligned}
$$

Table 4- Fibrin degradation product levels (FDP), fibrinogen plasmatic levels and platelet aggregation activity for six patients studied.

\begin{tabular}{cccl}
\hline $\begin{array}{c}\text { Patients studied } \\
(\mathrm{n}=6)\end{array}$ & $\begin{array}{c}\text { FDP levels } \mu \mathrm{g} / \mathrm{ml} \\
(\text { normal }<10 \mu \mathrm{g} / \mathrm{ml})\end{array}$ & $\begin{array}{c}\text { Fibronogen mg\% } \\
(\text { normal: } 200 \mathrm{a} \mathrm{400)}\end{array}$ & $\begin{array}{c}\text { Platelet activity } \\
\text { ADP } 1 \mu \mathrm{m}\end{array}$ \\
\hline 1 & $>40$ & 250 & hypofunction \\
2 & $10-40$ & 250 & hypofunction \\
3 & $<10$ & 310 & normofunction \\
4 & $10-40$ & 111 & hypofunction \\
5 & $>40$ & 136 & normofunction \\
6 & $>40$ & - & hypofunction \\
\hline
\end{tabular}


Iuan FC, Thomazini IA, Carvalho I, Carreira DMG, Cassinelli VJ, Pereira PCM, Barraviera B. Evaluation of platelet number and function and fibrinogen level in patients bitten by snakes of the Bothrops genus. Revista da Sociedade Brasileira de Medicina Tropical 28:19-24, jan-mar, 1995.

possible action of "factor X activator" and "thrombin-like" fraction from $B$. jararaca venom may explain these alterations. "Factor $\mathrm{X}$ activator" from $B$. jararaca venom transforms factor $X$ from blood into activated factor $X$. Prothrombin is transformed into thrombin by activated factor $\mathrm{X}$. Thrombin is capable of producing fibrin by acting on fibrinogen ${ }^{16}$.

Thrombin-like fractions act directly on fibrinogen molecule transforming it into fibrin. This effect is similar to that of human thrombin.

In this way, there will be plasmatic fibrinogen consumption and formation of fibrin degradation products(FDP) 10111222 as final consequences.

Bothrops venom besides acting on fibrinogen, also presents an effect on platelet, both in number and in function 672122 .

Prado-Franceschi et alii ${ }^{17}$ studying rabbits inoculated with Crotalus durissus terrificus venom, observed a discreet low number of platelets and an increase in platelet aggregant activity. Zingali et alii $^{27}$ described that pure Bothrops venom has a fraction that can stimulate platelet aggregation. These authors ${ }^{27} 28$ in 1992, described a new component of Bothrops venom which might inhibit platelet aggregation when induced by thrombin. Thomazini et alii ${ }^{23}$ observed platelet hypofunction in patients bitten by Crotalus durissus terrificus, when this was stimulated by $1 \mu \mathrm{m}$ ADP. In this work platelet number decreased until 8 days after specific treatment. Platelets also showed hypoaggregation when stimulated by $1 \mu \mathrm{m}$ and $3 \mu \mathrm{m}$ ADP. Patients who presented high FDP levels were those who had platelet hypofunction. Marcus ${ }^{1011} 12$ demonstrated the anti-aggregant action of fibrin degradation products. According to Santoro et alii ${ }^{22}$, platelet hypoaggregation observed may be explained by high levels of circulating FDP, which would have an inhibitory action on platlets due to competition with aggregant agents in platelet receptors. Vargaftig et alii ${ }^{24}$ evaluating convulxin fraction effect of Crotalus durissus terrificus observed that this fraction presented an aggregant action in vitro. Aggregation would occur by stimulating platelet receptors, releasing thromboxane $\mathrm{A}_{2}$, the platelet enzyme that facilitates platelet adhesion and aggregation mechanisms to the vascular subendothelium ${ }^{24}$. This action would lead to exhaustion of platelet reserves of thromboxane $A_{2}$, causing hypofunction. In the present study, we observed normalization of platelet aggregation curves on the $8^{\text {th }}$ day after specific treatment. As platelet medium lifetime is 8 days, it is possible that aggregant function recovery occur, by renewing platelets in blood circulation.

According to Benett and Vilaire ${ }^{3}$, platelets need a suitable level of extracellular fibrinogen for perfect functioning. When these levels are decreased, there is a loss of potency of aggregant agents on receptors causing, in the least analysis, an aggregation decrease.

In conclusion, patients bitten by Bothrops snakes presented fibrinogen consumption, platelet hypofunction and increased fibrinogen degradation products (FDP), suggesting a relationship among these factors.

\section{RESUMO}

Foram avaliadas a função plaquetária e os niveis séricos de fibrinogênio em 14 doentes picados por serpentes do gênero Bothrops, sendo 10 do sexo masculino e 4 do sexo feminino, com idades compreendidas entre 13 e 59 anos. Houve diferença estatística $(p<0,05)$ entre os niveis séricos de fibrinogênio avaliados 24 e 48 horas após o acidente. Houve tendência à normalização após 48 horas do tratamento. A plaquetopenia foi evidente nas avaliações de 24 e 48 horas. Houve tendência à nomalização no $8^{\circ}$ dia após o tratamento $(p<0,05)$. $A$ função plaquetária, quando estimulada pelo colágeno e epinefrina, apresentou-se dentro da normalidade. Quando estimulada pelo ADP, foi hipoagregante na concentração de 1 micromolar até 48 horas após o tratamento. Na concentração de 3 micromolar houve alteração apenas antes do tratamento especifico $(p<0,05)$. Os niveis de produtos de degradação de fibrina (PDF) mostraram-se alterados em $83,33 \%$ dos pacientes avaliados. Os autores sugerem que a hipoagregação esteja relacionada com niveis baixos de fibrinogênio e elevados de PDF.

Palavras-chaves: Funçãoplaquetária. Fibrinogênio. Produtos de degradação de fibrina. Bothrops. 
Iuan FC, Thomazini IA, Carvalho I, Carreira DMG, Cassinelli VJ, Pereira PCM, Barraviera B. Evaluation of platelet number and function and fibrinogen level in patients bitten by snakes of the Bothrops genus. Revista da Sociedade Brasileira de Medicina Tropical 28:19-24, jan-mar, 1995.

\section{ACKNOWLEDGMENTS}

The authors wish to thank Dr. Francisco Humberto de A. Maffei and Dr. Paulo Eduardo de A. Machado for their cooperation, Denise $H$. Francisco and Ivanete F. Amaral, Hemostasy Laboratory technicians, for their assistance and Dr. Paulo Roberto Curi for the statistical analysis.

\section{REFERENCES}

1. Barraviera B. Estudo clínico dos acidentes ofídicos. Revisão. Jornal Brasileiro de Medicina 65:209-250, 1993.

2. Barraviera B, Bonjorno Jr. JC, Arakaki D, Domingues MAC,Pereira PCM, Mendes RP, Marcondes-Machado J, Meira DA. A retrospective study of 40 victims of Crotalus snake bites. Analysis of the hepatic necrosis observed in one patient.Revista da Sociedade Brasileira de Medicina Tropical 22:512, 1989

3. Benett SJ, Vilaire G. Exposure of platelet fibrinogen receptors by ADP and Epinephrine. Journal of Clinical Investigations 64:1393-1401, 1979.

4. Berquó ES, Souza JMP, Gotlieb LD. Bioestatística. São Paulo,Editora Pedagógica e Universitária, 1980.

5. Helena Laboratories, Beaumont, Texas.

6. Kamiguti AS, Matsunaga S, Spir M, Sano-Martins IS, Nahas L. Alterations of the blood coagulation system after accidental human inoculation by Bothrops jararaca venom. Brazilian Journal of Medical Biology Research 19:199-204, 1986.

7. Kamiguti SA, Cardoso JLC. Haemostatic changes caused by the venoms of South American snakes. Toxicon 27:955-963, 1989.

8. Kornalik F. The influence of snake venoms of fibrinogen conversion and fibrinolysis. Memórias do Instituto Butantan 33:179-188, 1966.

9. Kouyoumdjian JA, Polizelli C. Acidentes ofídicos causados por Bothrops moogeni: correlação do quadro clínico com o tamanho da serpente. Revista do Instituto de Medicina Tropical de São Paulo 31:84-90, 1989.

10. Marcus AJ. Platelet function. (First of three Parts). New England Journal of Medicine 280:1213-1220, 1969.

11. Marcus AJ. Platelet function. (Second of three Parts). New England Journal of Medicine 280:12781284, 1969.

12. Marcus AJ. Platelet function. (Third of three Parts). New England Journal of Medicine 280:
1330-1335, 1969.

13. Marlas G, Joseph D, Huet C. Isolation and electron micrososcope studies of a potent platelet aggregating glycoprotein from the venom of Crotalus durissus cascavella. Biochimie 65:405-416, 1983.

14. Marlas G, Joseph D, Huet C. Subunit structure of a potent platlet-activating glycoprotein isolated from the venom of Crotalus durissus cascavella. Biochimie 65:619-628, 1983.

15. Marshall LR, Hermann RP. Australian snake venoms and their "in vitro". Effect on human platelets. Thrombosis Research 54:269-275, 1989.

16. Nahas L, Denson KWE, MacFarlane RG. Thrombinlike and factor X-activator components of Bothrops snake venoms. Thrombosis and Haemostases 41:314-328, 1964.

17. Prado-Franceschi J, Tavares DA, Hertel R, Lobo de Araújo A. Effects of convulxin, a toxin from rattlesnake venom, on platelets and leucocytes of anesthetized rabbits. Toxicon, 19:661-666, 1981.

18. Rattnoff DO, Menzie C, Baltimore AB. A new method for the determination of fibrinogen in small samples of plasma. Journal of Laboratory and Clinical Medicine, 37:316-320, 1951.

19. Rosenfeld G. Acidentes por animais peçonhentos. In: Veronesi $\mathrm{R}, 8$ ed. Doenças Infecciosas e Parasitárias. Guanabara Koogan, Rio de Janeiro, p. 951-962, 1991.

20. Rosenfeld G, Hampe OG, Kelem EMA. Coagulant and fibrinolitic activity of animal venoms; determination of coagulant and fibrinolitic index of different species. Memórias do Instituto Butantan 29:143-163, 1959

21. Sano-Martins I, Kamiguti AS, Chnudzinski AM, Santoro ML, Tomy SC, Castro SCB and Kelen EMA. Estudo hematológico em pacientes com sangue incoagulável decorrente de envenenamento botrópico. In: Anais do I Simpósio da Sociedade Brasileira de Toxinologia, São Paulo, p.22, 1990.

22. Santoro ML, Sano-Martins IS, Chamone DAF. Blood platelets during experimental Bothrops jararaca envenoming. I - Aggregation study. In: Annals of IV PAN American Symposium on Animal, Plant and Microbial Toxins, II Symposium of the Brazilian Society on Toxinology, Campinas, p.104, 1992.

23. Thomazini IA, Iuan FC, Carvalho I, Hernandes D, Amaral IF, Pereira PMC, and Barraviera B. Evaluation of platelet function of serum fibrinogen levels in patients bitten by snakes of the genus Crotalus. Revista do Instituto de Medicina Tropical 
Iuan FC, Thomazini IA, Carvalho I, Carreira DMG, Cassinelli VJ, Pereira PCM, Barraviera B. Evaluation of platelet number and function and fibrinogen level in patients bitten by snakes of the Bothrops genus. Revista da Sociedade Brasileira de Medicina Tropical 28:19-24, jan-mar, 1995.

de São Paulo 33:219-220, 1991.

24. Vargaftig BB, Prado-Franceschi J, Chignard M, Lefort J,Marlas G. Activation of guinea-pig platelets induced by convulxin, a substance extracted from the venom of Crotalus durissus cascavella. European Journal of Pharmacology 68:451-464, 1980.

25. World Health Organization. Progress in the characterization of venoms and standardization of antivenoms. World Health Organization. Offset. Publication 58:1-44, 1981.

26. Zappelini A, Prado-Franceschi J. Efeito do veneno de Bothrops erythromelas na agregação plaquetária. In:Anais do I Simpósio da Sociedade Brasileira de
Toxinologia, São Paulo p.17, 1990.

27. Zingali RB, Carlini CR, Francischetti IM, Guimarães JA.Bothrops jararaca snake venom: Effects on Platelet aggregation. Thrombosis Research 58:303$316,1990$.

28. Zingali RB, Jandrot-Perrus M, Guillin MC, Bon C. Characterization of a Platelet inibitory protein isolated from Bothrops jararaca venom that interacts with thrombin. In: Annals of IV PAN American Symposium on Animal, Plant and Microbial Toxins, II Symposium of the Brazilian Society on Toxinology, Campinas p.33, 1992. 